\title{
英国1934年港湾荷役規則について
}

\section{About The Docks Regulations, 1934 of England}

\author{
東 海 林、滋 ( (神戸商船大学)
}

\begin{abstract}
We shall have a regulation for the safety of cargo-handling onboard before long and it will, I hear, follow the Docks Requlations, 1934 of England, which I introduce here.

1. legislative position of, internal and international

2. birds-eye view of it, compared with the convention, 1932

3. some cases about it

We haue many to learn from this regulation-especially from its construction and operation. Now let us train our students enough to fulfil their duties on the cargo-handling on board.
\end{abstract}

\section{は し が き}

吾々は戦争のため，各国港湾飞特ける安全管理の見地から発详しそ荷役関係の規則に刘しても 全く空白の時を過して来たので，…国際海運の激しん競争裡にあつてての方面で霬々不利な体 験を重称て来を-Pacific Coast Marine Safety Code の訳者（O.S. K. 水交会）は刊行の 辞でてのよ5にんわれている，港湾荷役の規則につんて統一的な展望をえることは必要である。 こてで紹介したんのは英国の1934年港湾荷役規則であるが，20年も前飞出をるのであるから，或 は旧聞に属するかもしれなん。

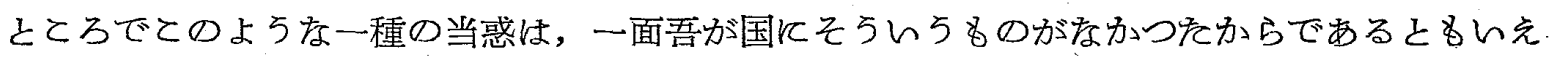
上5. 周知のように，船舶安全法（第 2 条）飞は，「何役其／他ノ作業 設倩（第 1 項）」が命 令の定め従つて施設さるべきととの規定があるが，ての命令がまだ整備されていない，又.「航 海上」危険防止につんては，安全法の第28条に基いて同施行規則の第17章に規定があるが，荷 役については見当らない，聞くとてろによると，とれらは近い将来に新しん一つの規則（船舶荷 役規則，第 1 次案 29 年 8 月 2 日）として出される模様であり，その内容は，専ら船側に対する規 制である点が異るが，大体英国等と同じようなものとなるらしん．敢て管見を綴る次第である，

\section{1. この規則の系譜}

英国では，The Factory and Workshop Act, 1901 (1 Edw. 7. C. 22) の中で若干の条 項を設けて港湾荷役のてとを規定していたが，特にその79条では，省令による特別規則の生れる ととを予定してんた，その許で1925年に Docks Regulations がつくられたが，国際的な動きとし て1932年K I. L。 O. が港湾荷役の安全飞関する条約 Convention (No. 32) Concerning the Protection against Accidents of Workers Employed in Loading or Unloading ship (Revised 1932) を採択したので，1）早速てれに同調して，先の規則学改豦し，1934年3月5日 法命第279号として出されたのがこの規則である。（条約の批准は連合王国として1935年1月10日 
である) その後法律の方が改められて The Factories, Act., 1937 となつたが，規則はそのま ま同法の許で施行されている。

I.L.O, . Safety in Dock Work (Montreal, 1945) のいうところによれば, 「港湾荷役の安全というこ とは，各国立法当局の多く注目するところであつた」(P.111).しかし，各国に括ける規制の形態は同一で ない. 現在どうなつているかよく分らないが，ドイッでは船主間及び卸売, 會庫篻者間の夫及相互摃害保険 組合で事故防止の規㲘 (1933年及び1934年) をつくつている.アヌリカでは，各港で委員会の手で volu一 ntary な code (New York, 1939; Pacific，1929-34) がつくられたが戦後学激協約の中に取入られた。 上述 Pacific Coast Maritime Code (最終訂正 1949. 9. 29) は, P.M.A. と I.L.W.U. との協的 Pacific Coast Longshore Agreement の Section 13 に取入れられて，效力を発揮しているのだ女る.又 最近では A.B.でも略同样の規則を設けている. 英国系諸国のものと共に揭げておく。

A.B., Regulations for the certification of the ccnstruction and survey of cargo gear on merchant vessels and code of recommended precautions against accidents connected with the loading and unloading of merchant vessels, 1952.

Australia, Navigation (Loading and Unloading) Regulations, 1941.

Canada, Regulations for the Protection Against of workers Employed in Loading or Unloading Ships, 1949. (条粎の批准㤝，1946年4月6日)

India, Indian Dock Labourers Regulations, 1948. (条約の批准は，1947年2月10日，パキスタンも同 日)

Pakistan, Pakistan Dock Labourers Regulations, 1948.

このよ弓に各国夫々のニュアンスガ賽われるのであるが，吾が国ではどのようになるであろろか。、今日 労働規制は海陸に二分されている.陸は学衔基準法二労働安全衛生規則 (昭 22 , 労働省命第 9 号)で, 海 は船員法や船船安全法で，というのであるが，荷役のような交字通り海陸協同作業の場合，こういう規制 のし方は甚げ不味いと思われる。文，外国船を規制する力はどうだろうか。色々な意味で，「この规則さ え出来れぼよい」といらのではない。さりとて，今日まで規則のなかつたことは，吾が国では荷役の安全 度が高かつ态ことを決して意味しない。現状即号次の如くである。

（A）船員の側 (1951；学研西部徵一氏発表のものによる)

(a) 災害千人率

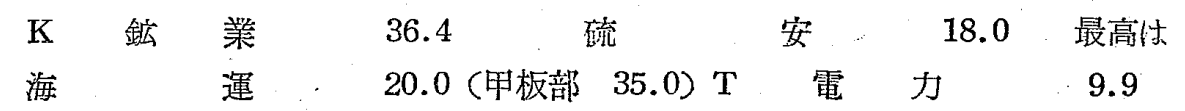

(b)甲板附近に招ける災害の作業別此率

\begin{tabular}{|c|c|c|c|c|c|}
\hline $\begin{array}{l}\text { 荷 } \\
\text { 役 }\end{array}$ & $\begin{array}{ll}\text { 大 } & \text { バ } \\
\text { タ } \\
\text { ン }\end{array}$ & $\begin{array}{ll}セ & 7 \\
1 & 1 \\
\ni & 1 \\
1 & ク\end{array}$ & $\begin{array}{cc}\text { 食 } & \text { そ } \\
\text { 澊 } & \text { の } \\
\text { 搬 } & \text { 他 }\end{array}$ & $\begin{array}{l}\text { 尔 } \\
\text { の } \\
\text { 他 }\end{array}$ & 計 \\
\hline 49.0 & 12.0 & 16.5 & 15.3 & 7.2 & 100.0 \\
\hline
\end{tabular}

(B) ステベの側（昭和28年度；学衔者「労働災害統計結果表」による）

\begin{tabular}{|c|c|c|c|}
\hline & 度 数 率 & 強 度 & 率 \\
\hline 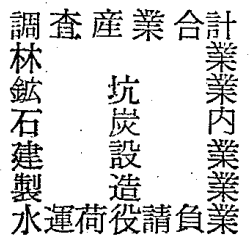 & $\begin{array}{r}32.96 \\
109.15 \\
93.48 \\
155.00 \\
63.85 \\
21.54 \\
121.95^{*}\end{array}$ & & $\begin{array}{r}2.95 \\
7.45 \\
9.18 \\
15.41 \\
7.89 \\
1.48 \\
6.99\end{array}$ \\
\hline
\end{tabular}

* 昭和 24 年度には 185.98 と極めて高 く，ために25年10月28日安全課長は 特に港湾学㣳の安全に努力するよう 全国に通澾している. 今日でる阪神 では船内で 300 近い数字を示す会社 がある。 


\section{2. 内 容の 鳥 瞰}

規則は，前文と6 部51条の項と附則とから索つている。

前文は先つ準拠法を明らかにし，適用上の（漁船，艀に対する，或は25年の規則飞関する）例 外をのべ，1934年 6 月 1 日を以て效力を発するてとを宣する。

次で, 若干の用語につんて定義をのべ（条約第 1 条に応が)，最後に規則の各部が，乙れ を守るとと何人の義務なるかを明らかにしている（条約第17条添添ら）簡記すると，

(a) Part I 守るのは，岸壁管理人 (person having the generel management and control of a dock, wharf, or quay) $の$ 義菻

(b) Part II は, 船 (Owner, master, or officer in charge of a ship) の義薪

(c) Part II は，機構設備の所有者，外国船の場合はその船長の義勏

(d) Part IV は, ステべ (every person who by himself, his agent, or workmen carries on the process, and all agents, workmen, and persons employed by him in the process) の義袎

(e) Part V 恃，すべての人の義務

(f) Part VI は，該当者の義務である。とん5のである，以下各条の要旨を見出し的に記し 条約の対応条番号を添えるとととする・ミ(イタリックは，特にそのままの形でみられる学働安全 衛生規則の条番号)。

[第 I 部]

条約

第 1 条 通路及び就業場所の安全

2(4) 100

2 : 溺者救助の設備

3 照明の実施

13

4 救急函の設置

2(1) 100

5 他のものを入れぬこと

13

6 鐩の保管

13

7 救急車の用意又は病院との連絡

13

8 救護施設の稪内揭示

[第 2 部]

9 船への通路

10 船同志横付けの場合

11. ホールドへの通路

12 船内の照明

13 ハッチビームの嵌脱装置

13

14 ハッチ蓋及びビームのマーク

15 ビーム及びハツチ蓋の維持

16 ハツチ蓋の取手

17. ハッチ周 bの最低余積

[第 III 部]

18 ウインチ，マスト，デリックの㮩查

19 チェン, リング。フック等の検查

20 ロープの検查

21 、検查官
3101

$3 \quad 101$

$5 \quad 102$

7

$8(3)$

$8(4)$

$8(1)$

$8(2)$

$9(1)$ 
22 検查証の保持

23 プロックの安全使用力を標示のとと.

24 スリングの安全使用力の標示

25 チェン使用上の注意

26 歯車, 蒸汽管等の囲い

27 ウインチの安全装置

28 クレーンの運䎐台

29 タレーン, デリックの安全使用力標示

9(5) $11(9)$

30 排汽等の処理

31 デリック脚部の冕脱防止

[第 IV 部]

32 撒荷の際の脱出考虑

33 オーバーローデイソグ及び途中放置の禁止 $11(8)(1)$

34 運転者の制限 10

35 岸壁上の整理 $2(2)(3) \quad 100$

36 足場及び手車の使用 $11(6)$

37．使わをんハッチの開放禁止

38 中角板の作業とハツチ䔔

39 ハツチ部分に限られた作業の昜合

40 スケルトンデッキでの作業

41 つつかい棒等の使用

42 ビーム索残して荷役する場合

43 合図人口便用

44 水上通行の安全

4

107

[第 $\mathrm{V}$ 部]

45 梱その他施設の除き禁止

46 特飞第 1 条飞規定の相につんて

47 指定の通路宗守るとと

3(6) $102(2)$

48. ビームの上に上ら㰠とと

[第 VI 部】

49 規則を守らぬ者は使わぬてと

50 9，10，12条以雇主にも義務がある

51 記録簿の提示

附則 機械及び用具検查の方法

\section{3. 規 則 の 運 用}

Geo. B. Lissenden 氏の揭げてんる判例の中から若干のものを拾つて, ${ }^{3)}$ ての規則赛施後の 様子をらかがらととにしょら。

(判例 1 ). Norwegian Shipping \& Trade Mission V, E. M, Behenna (1943) 一ウイン チの故障を值しておかなくて生じを損害は船の責任。

ウインチマンは，蒸気をコントロールするスピンドルの具合の覀いととを本船の士官に訴えた が，甲機士官はとれを知り乍ら放置して歌た。荷役が終つたとき，ウインチマンはカーゴーフ 
ツクをウインチのフレームとかけ，てれを張合せを時フレームをてわした。判決では，ウインチ マンに過失のあると亡は，認められたが，本船の側もステべに対する義務違反があつたとして， 訴訟は却けられを。

（判例 2 ）Liddell v. Union Steamship Co. of New Zealand Ltd. (1935) 一一荷役江関 係のない場所での怪俄は船と責任なし。

原告は，シェルターデッキで「ダンネーギを集めていて」ハッチから落らを。しかし，笑際は そのハツチはその折の荷役に関係なかつを，判事 Greaves 唧は日く，開放されたハツチをガー ドする義務は，積荷又は揚荷のため反使用されてんるハッチに限琴される。原告が明りを要求す るでもなしに本船のそ5んら暗ん所へ勝手に行つたのだ。とすれば，事故の責任は彼自ら真らべ きであると。

Hengham v。 Roderiet Forangrene (1936) の場合飞は，原告は材木揘げのためとスキツド をよりKブリッデズペースへ入り，バンカーハッチへ落ちて大怪俄をした。被告のためには，ス キッドはそとには和いてなかし；原告は家屋侵入者であつをと弁ぜられた。しかし原告はその 場所へ行つてならぬとを知らなかつたし，被告は，荷揚げの折にはその所の使われるととを知 つていたととを認めた。結局，てのスェーデンの船主は 1200 ポンドと訴訟費用とを払わせらられ ている.

(判例 3 ) Colfer v. Coggins and Griffiths (1942)—スッングの袋数丈では “Safe system"の判別炕なら奴。

袋入りの塩を積込中コーミングに当つて落ら原告が怪俄をした。訴訟では，スリングの袋数が 多すぎた。 それ故雇主㤌 (1880年の Employers' Liability Act の規定する) “Safe system of working”を整えなかつを責任がある，と主張された。 Stable 判事の判決によると, 事故の起 る前には袋数につんて苦情は出てんるん，抑もスリングの袋数は，原告分櫵人のんらように規則 できびしく定めるべきものではなく，積荷にあたる人間の経験にまつべきものである，之。（契 み反，上述 Pacific Coast Iorgstore Agre€ment では Sec. 13 で sling load limit を定 めている.)

同じように，作業の状態が果して Safe system であつそかぎらかについて，んくつかの判例

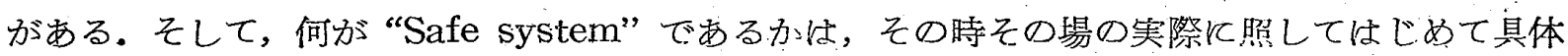
的決定せられる。雇主は，てのよらを細かん点につんて一及注意を与えるてとを，誰か反委せ

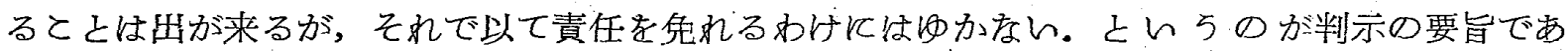
る。吾及はことにも彼の国に郝ける現場への信頼と尊敬とを看取するととが出来るのであるが， 次の判例は，荷役業務の乃全を期そ5とする関係者の努力をよく物語つていると思う。

(判例 4 ) Malone v. Imperial Chemical Industries (1939)—ステべは引受けを時の状 態で仕事をはじめべきである。

判決に当つて Lewis 判証日く「ょしんば積付が悪かつをこしても，ステべはその貨物を， 見出した状熊で取扱らべをである。ステべの仕事が容易ならぬものであるととは誰しもの認める ところであるが，幸いに吾が国殊にてのリバプールでは，ての極めて複雑な代事をやりてをす能

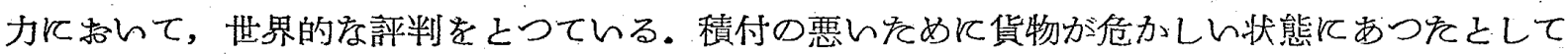
も，自分達の手でそれを直すととをしなかつをならば，ステべは事故の責任を船主に押付けるわ

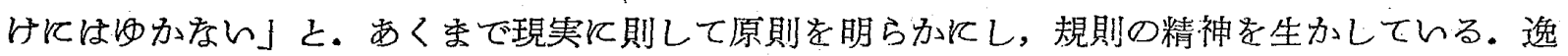
早くこうしを規則を設けながら，しかも昔からの伝統を忘れまい。相互の信頼と努力とによつて 健全な常識が養和れ，それによつて運用されている Docks Regulations は，やはり「古くして 
新しん」規則であるとんえよう。

結

$\mho$

英国の港湾荷役規則はどのよ5繁りをもち，ぞのような内容のものであるか，又どのよらに 運用されているか，簡単ではあるが以上の如くである，将に生れんとする吾が国の規則が，規制 形態のギゴチナサを克服して，船船荷役の安全を通じて吾が国海運及び港運業の発展に資するて とを祈つてやをない。

勿論, 規則のあるなしに拘らす「荷役の作業員や公務で船へやつてくる人及の安全とんらとと

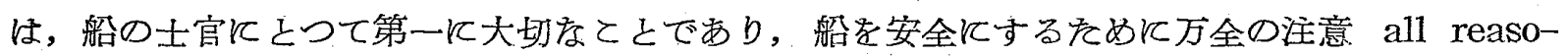
nalbe precautions を払らここが士官の責㹣であることは一一敢て英書走引き「Common Law

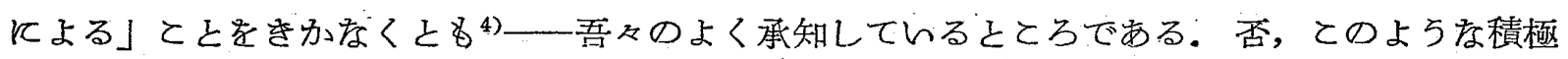
的認識とそは，ビジネスとしては佮未成年であるわが国海運に和いて，よく Common Lawの 久如を補つてきたるのであるといえよう。今日吾々の問題は，ての認識の根底を探つて真にゆる きない基礎に据えることである。

最近の英誌々夕られそ次の如き寸言も，その意味で亦一顧の佂值をもつのではなからか。日 $<$ _- "Train people, by all means, but as sailors, in this problem of loading our ships, let us keep our feet firmly on the ground and our ships seaworthy ${ }_{5}$ " $z$.

29-12-22

1）今日までの批准国は次の17ヶ国で㚣り，1934年10月30日条約として発效しているが，批准国の夕を 拘束する (20条) ので, 吾吕国ては数力がない。ウルグフイ (1933.6.6)，イタリー-(1933.10.30) メキシコ，スペイン，連合王国，中烡民国，チリー，ニ土ージーランド，スウェーデン，カナダ，イ ンド，パキスタン，フインランド、ブルガリヤ,アルゼンチン，ベルギー及びキニーバ (1954.9.7) 份 I.L.O.では，これよりさき1929年に，1ケの総重量が1ton 以上の貨物にはその重量を標示すべ き旨の条約 (No. 27) を採択した（学安 123 条恃之と同意). 又1937年に, 港湾荷役の専門書を出 すことを決め，1945年これを実現した．Safety in Dock Work (I.L.O. Studies and Reports， Series F, Second Section (Safety), No. 10, iv+225p.) がそれである.

2）このような事情で, Docks Regulations は Factories Act の名と共に呼称されるのが常である そ.cf, Capt, K. Mac Donald, The Docks Regulations (Factories Act 1937) Explained, Glasgow, 1953, p.9

3) Ges. B. Lissenden; Stevedorès Handbook, Glasgow, 1949

4) Bonwick and Steer, Ship's Business, Wokingham, 1953, p.188

5) The Nautical Magazine, 1954 May issue, p.xv 